\title{
Importance of Trace Fossils and Bioturbation in Carbonate Reservoir Characterization and Reservoir Quality: Examples from the Khuff Formation
}

\author{
Dirk Knaust (Statoil, <dkna@statoil.com>)
}

Several aspects of the study of trace fossils (ichnology) are relevant for the characterization of carbonate reservoirs, of which the following are most important: (1) facies interpretation by utilizing the ecological information of trace fossils and ichnocoenoses; (2) reservoir zonation by identifying sequence boundaries and flooding surfaces for correlation; and (3) reservoir quality and connectivity, which is directly affected by bioturbation. The vast shallow-marine carbonate platform of the Middle Permian to Lower Triassic Khuff Formation in the Middle East comprises broad facies belts with little significant changes in the lithofacies. However, trace fossil assemblages and ichnofabrics, in combination with sedimentological observations, serve in subdividing this platform and in distinguishing sub-environments. From proximal to distal, these are sabkha and salina, tidal flat, restricted lagoon, open lagoon, platform margin, shoreface/inner ramp, slope/outer ramp and basin/deeper intra-shelf. In this way, changes in relative sea level can be better reconstructed and guide the sequence stratigraphic interpretation.

Meter-scale shallowing-upward cycles dominate the succession and, in addition to conventional methods, bioturbation, trace fossil assemblages and tiering patterns aid in interpreting subtidal, lower and upper intertidal and supratidal portions of these peritidal cycles. Bioturbation (and cryptobioturbation) have an impact on the primary reservoir quality before diagenetic processes overprint the deposits. For instance, deposit-feeders (such as vermiform organisms) introduce a certain amount of mud and decrease porosity and permeability considerably, whereas others like the Zoophycos-producers fill their dwellings with ooid grains and turn a mudstone from a barrier to a flow unit. This novel study demonstrates the value of ichnological information in carbonate reservoir characterization and the significance of trace fossil analysis in facies interpretation, reservoir zonation and the impact of bioturbation on the reservoir quality. Finally, a semi-quantitative analysis of the endobenthic activity across the Permian/Triassic boundary (PTB) enables for the first time the evaluation of recovery of endobenthic organisms after the end-Permian mass extinction by direct comparison of post-extinction (Lower Triassic) with pre-extinction (Upper Permian) units. 